Ann. Biol. anim. Bioch. Biophys., 1978, 18 (2 B), 607-613.

\title{
Effects of FSH and testosterone on Sertoli cells and spermatocytes from rat testis
}

\author{
by F. F. G. ROMMERTS, J. A. GROOTEGOED, H. J. VAN DER MOLEN (1) \\ Department of Biochemistry (Division of Chemical Endocrinology), Medical Faculty, \\ Erasmus University Rofterdam, Rofferdam, The Netherlands.
}

Summary. Several biochemical parameters have been studied in isolated Sertoli cells and germinal cells from rat testis. Androgen receptors have been demonstrated in Sertoli cells, but not in germinal cells obtained from the same testis tissue.

Isolated Sertoli cells when incubated with ${ }^{3} \mathrm{H}$-leucine secreted in addition to androgen binding protein (ABP) many different labelled proteins. The secretion of these proteins was stimulated in the presence of testosterone, FSH or dibutyryl cAMP. In addition Sertoli cells appeared to secrete an inhibin-like substance. In isolated pachytene spermatocytes incorporation of ${ }^{3} \mathrm{H}$-uridine into RNA remained constant for $8 \mathrm{hrs}$ and decreased thereafter. A relatively high incorporation into $32 \mathrm{~S}$ rRNA, rather than $28 \mathrm{~S}$, was apparent from the electrophoretic profile of labelled RNA and might reflect a delay of the processing of ribosomal RNA in spermatocytes.

\section{Introduction.}

It has been known for a long time that completion of spermatogenesis does not occur after hypophysectomy (Clermont and Harvey, 1967) and many different functions of the festis appear to be regulated by pituitary and testicular hormones. Little is known about the molecular mechanisms which are involved in regulation of spermatogenesis, but several observations support the view that the effects of follitropin (FSH) and testosterone on germinal cells might be mediated via the Sertoli cells.

Thus far no evidence has been found for a direct action of follitropin or androgens on germinal cells, whereas Sertoli cells are certainly under the influence of follitropin and androgens (Louis and Fritz, 1977) and the presence of a receptor specific for androgens (including testosterone) has been demonstrated in Sertoli cells (Grootegoed ef al., 1977a).

(1) Correspondence to : H. J. van der Molen, Department of Biochemistry II.

Medical Faculty Erasmus University Rotterdam.

P. O. Box 1738 Rofferdam The Netherlands. 


\section{Receptors for androgens in isolated testicular cell types.}

The localization of androgen receptors might help to define the cell types of the seminiferous epithelium which could be influenced directly by androgens. In order to investigate this, cell preparations enriched in either germinal cells or Sertoli cells were isolated from testicular tissue of rats 30-35 days of age and these preparations were incubated with ${ }^{3} \mathrm{H}$-testosterone. Radioactive steroid was specifically bound to receptors extracted with $0.4 \mathrm{M} \mathrm{KCl}$ from the nuclear fractions of Sertoli cell aggregates (Mulder et al., 1975 ; Grootegoed et al., 1977a). In the isolated germinal cells (spermatocytes and round spermatids) only a negligible amount of testosterone was bound to nuclear material. Our results would suggest therefore, that receptors for androgens are present mainly in Sertoli cells and not in germinal cells.

Other authors have presented results which were considered to reflect specific binding of androgens to germinal cells (Sanborn ef al., 1975 ; Galena et al., 1974). However, in these studies limited physico-chemical characterization of the binding proteins in germinal cells was performed and it is therefore not clear whether this binding activity reflects receptor binding. Further support for the idea that androgens do not directly act on germ cells via an androgen receptor, came from genetic studies by Lyon et al. (1975), who showed that spermatozoa with a Tfm gene could be generated in mice chimaeric for the androgen-resistani ( $\mathrm{Tfm} / \mathrm{y})$ and normal $(+/ \mathrm{y})$ genotype. Because there are now several examples showing that $\mathrm{Tfm}$ cells lack an androgen binding receptor, it appears unlikely that the development of such $\mathrm{Tfm}$ spermatozoa would have involved an androgen receptor.

\section{Effects of hormones on secretion products from Serfoli cells.}

The nature of possible interactions between Sertoli cells and germinal cells is still not known. For a long time morphological evidence gave the impression that junctions between Sertoli cells and germinal cells did not exist (Fawcett, 1975). Therefore, several attempts were made to study the secretion of substances from isolated Sertoli cells which could be transferred to germinal cells and might influence the development of spermatogenesis. Recently, however, more refined electron microscopic studies have suggested that certain junctions may connect Sertoli cells with germinal cells (Russell, 1977). Such junctions would of course be disrupted when studying isolated cells, which could limit the relevance of the results obtained. In our experimenis we have studied with isolated Sertoli cells the secretion of newly synthesized proteins, androgen binding protein, œstradiol-17 $\beta$ and inhibin-like material, as well as the effects of trophic hormones and steroids on these secretions.

Isolated Sertoli cells from 21-24-day old rats can be maintained in culture for more than 25 days and remain responsive to $\mathrm{FSH}$ and testosterone for more than 6 days. The secretion of androgen binding protein (ABP) was stimulated (260-330 p. 100 when compared to controls) when cells were cultured in the presence of FSH $(5 \mu \mathrm{g} / \mathrm{ml})$, testosterone $(200 \mathrm{ng} / \mathrm{ml}$ ) or dibutyryl cyclic AMP (DcAMP, $0.1 \mathrm{mM}$ ). During the culture period a drop in the daily production of $A B P$ was observed, however, even 
when the cells were culfured in the presence of hormones. Estradiol-17 $\beta\left(E_{2}\right)$ secretion has also been measured when cells were incubated in the presence of testosterone and FSH. The daily production was between 200 and $600 \mathrm{pg} \mathrm{E}_{2} / \mathrm{mg}$ cellular protein and the secretion remained consiant or increased during culture periods for more than 20 days.

For investigation of other secreted proteins, in addition to $A B P$, culture media were analyzed after incubation of Sertoli cells with ${ }^{3} \mathrm{H}$-leucine $\left(5 \times 10^{7} \mathrm{dpm}\right.$ in $5 \mathrm{ml}$ culture medium). After each 24-hr. incubation period $5 \mathrm{ml}$ culture medium was aspirated and the macromolecules (M.W. $>10000)$ were concentrated $(50$-fold) by ultrafiltration with single hollow fibres (Rommerts ef al., 1977). ${ }^{3} \mathrm{H}$-leucine was removed by dialysis and the concentrated medium was used for estimation of the amount

$$
\times 10^{3} \mathrm{dpm}
$$

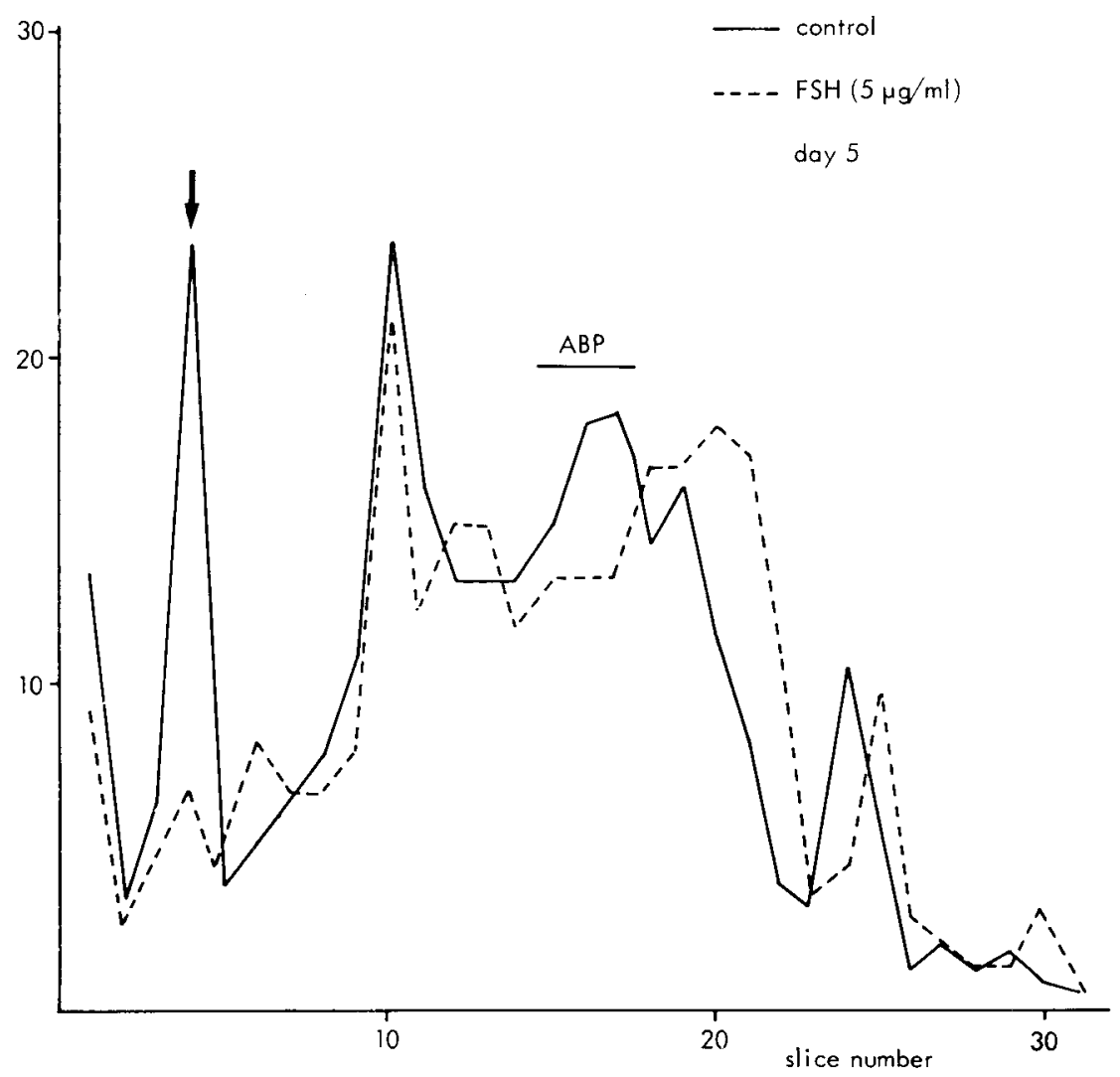

FIG. 1. - Electrophoretic pattern of secrefed ${ }^{3} \mathrm{H}$-labelled proteins after incubation of Sertoli cells with ${ }^{3} \mathrm{H}$-leucine for $24 \mathrm{hrs}$ at $32^{\circ} \mathrm{C}$. Culfure medium was concentrated by ultrafiltration and dialyzed to remove ${ }^{3} \mathrm{H}$-leucine. Sertoli cells were obtained from prenatally irradiated rats (22 days old) and were kept in culture for 6 days without hormone $(-)$ and in the presence of FSH $(---)$. The horizontal bar indicates the position of binding activity of ABP estimated by selective extraction of sH-dihydrotestosterone from the same gel and the arrow indicates the incorporation of activity from ${ }^{3} \mathrm{H}$-leucine in a protein which appears to be clearly under the influence of hormones. 
of radioactivity incorporated into macromolecules (Table 1) as well as for qualitative analysis of the macromolecules (fig. 1) on polyacrylamide gel electrophoresis. It was shown that the isolated products are proteins, and differences in the electrophoretic profiles of proteins in cytosols and culture medium (in addition to observations on other markers) indicated that maximally 7 p. 100 of the extracellular proteins could originate from leakage of deteriorated cells. The amount of labelled proteins in the culture medium was increased when cells had been cultured with FSH or testosterone, but not when cultured with compounds like albumin or cortisol. No specific effects of hormones, except for one peak, were observed when protein profiles from cells under different incubation conditions were compared (fig. 1 and table 2). The different proteins may contribute to the specific composition of intratubular fluid which may be important for differentiation of spermatogenic cells.

\section{TABLE 1}

Effect of hormones on secretion of radioactively labelled proteins after incubation of Sertoli cells with ${ }^{3} \mathrm{H}$-leucine

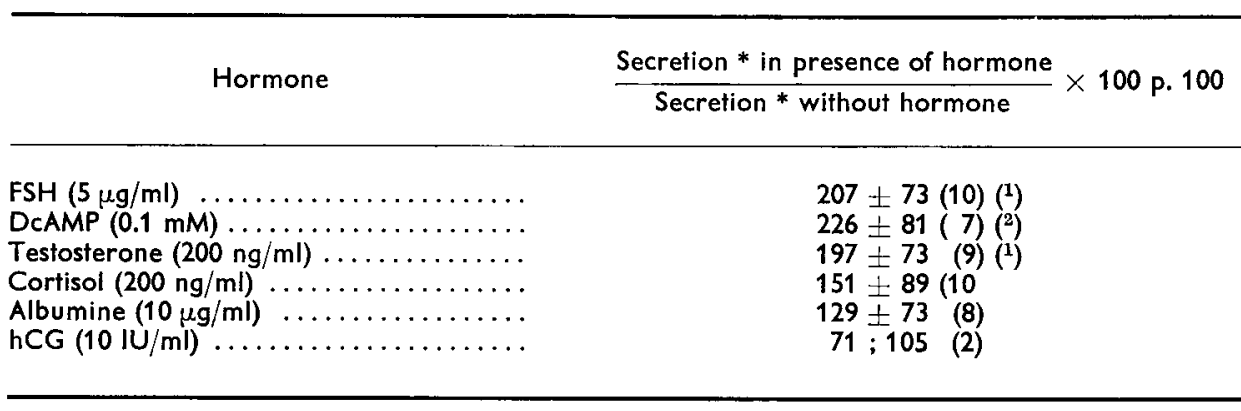
0.02 .

* dpm present per mg cellular protein. $\left({ }^{1}\right)$ Wilcoxon's test : $\mathrm{p}<0.01 ;\left({ }^{2}\right)$ Wilcoxon's fest : $\mathrm{p}=$

TABLE 2

Effect of hormones on secretion of radioactively labelled proteins after incubation of Sertoli cells with ${ }^{3} \mathrm{H}$-leucine

\begin{tabular}{|c|c|}
\hline Incubation condition & $\begin{array}{l}\frac{\text { Area of front peak }}{\text { Area of all peaks }} \times 100 \text { p. } 100 \\
\text { (mean } \pm \text { SEM) }\end{array}$ \\
\hline $\begin{array}{l}\text { No hormones } \ldots \ldots \ldots \ldots \ldots \ldots \\
\text { Testosterone }(200 \mathrm{ng} / \mathrm{ml}) \ldots \ldots \ldots \ldots \\
\text { FSH }(5 \mu \mathrm{g} / \mathrm{ml}) \ldots \ldots \ldots \ldots \ldots \ldots \ldots \\
\text { FSH }+ \text { testosterone } \ldots \ldots \ldots \ldots \ldots \ldots\end{array}$ & $\begin{array}{l}9.8 \pm 0.8(20) \\
8.6 \pm 1.3(7) \\
2.7 \pm 0.3(12) \\
2.3 \pm 0.3(4)\end{array}$ \\
\hline
\end{tabular}

In other experiments (by de Jong) it was demonstrated that factors were present in culture medium from Sertoli cells that could influence gonadotrophin secretion of pituitary cells in culture. Estradiol- $17 \beta$ has been shown to reduce LH-stimulated 
testosterone production by isolated Leydig cells when administered to hypophysectomized immature rats treated with FSH (van BEURDEN ef al., 1976). Regulation of pituitary function by secretion products of Sertoli cells (inhibin) and regulation of testosterone production in Leydig cells by estradiol may reflect a feed-back system between Sertoli cells and the extratubular cells which control Sertoli cell function.

\section{Effects of hormones on RNA synthesis in spermatocytes.}

Apart from the lack of daia on the interactions between Sertoli cells and germinal cells, there is liftle information about the molecular processes which are involved in (the regulation of) spermatogenesis. The incorporation of aminoacids and nucleotides into proteins and nucleic acids has been previously studied with autoradiographic techniques. It may be expected that changes in the developing germ cell could involve changes in the synthesis of (specific) ribonucleic acids. Therefore we have attempted to characterize with biochemical techniques the synthesis of RNA in isolated primary spermatocyles (pachytene stage, prophase of the first meiotic division) from rat testis (Grootegoed ef al., 1977b). Primary spermatocytes were used because a quantitative efficient development of this cell type depends on the presence of hormones and because it is possible to isolate these cells in a relatively pure form.

Isolated spermatocytes remain active with respect to RNA synthesis for approx. 20-50 hours, but cell viability is lost when isolated cells are kept in culture for more than a few days. The incorporation of ${ }^{3} \mathrm{H}$-uridine into RNA in the isolated cells is cons-

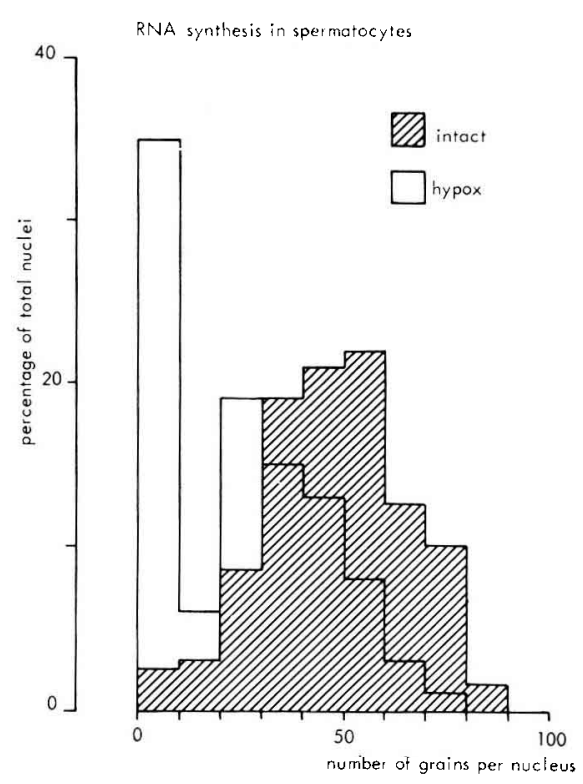

FIG. 2. - Autoradiography of isolated spermatocytes incubated with ${ }^{3} \mathrm{H}$-uridine for $2 \mathrm{hrs}$. The number of grains per nucleus of at least 200 pachytene spermatocytes from 2 different cell preparations were counted. Spermatocytes were isolated either from intact rats (29 days old) or from rats $64 \mathrm{hr}$ after hypophysectomy. 
fant during the first 8-10 hours and the labelled RNA appears qualitatively comparable with the RNA synthesized in cells labelled in vivo. The RNA species synthesized from ${ }^{3} \mathrm{H}$-uridine are mainly heterogenous RNA's with a short half-life and ribosomal RNA's. A predominant synthesis of $32 \mathrm{~S}$ ribosomal RNA was observed, which could reflect that in spermatocytes cleavage of $32 \mathrm{~S}$ precursor RNA to $28 \mathrm{~S}$ RNA was retarded. This $32 \mathrm{~S}$ ribosomal RNA peak was not observed in RNA isolated from preparations enriched with Sertoli cells or spermatids

Hormonal effects on spermatocytes (indirectly or directiy) were investigated by a comparison of in vitro RNA synthesis in spermatocytes from intact rats (28-30 days old) and rats 3 days after hypophysectomy. The electrophoretic profiles of the labelled RNA's from the two different cell preparations did not show any difference, but spermatocytes from hypophysectomized animals showed a 50 p. 100 decrease in incorporation into acid precipitable material and also a 50 p. 100 decrease in cellular uptake of ${ }^{3} \mathrm{H}$-uridine. These effects of hypophysectomy could be partially prevented by treatment of the rats with daily injections of FSH and testosterone. The same consequences on qualitative and quantitative RNA synthesis could be partly solved after characterization of the two different cell fractions with autoradiographic analysis of RNA synthesis. The spermatocyte preparations from intact and hypophysectomized rats were rather different. Spermatocytes from hypophysectomized animals contained many inactive cells, but cells with very active RNA synthesis were also present (fig. 2). A general obligatory effect of hormones on RNA synthesis in spermatocytes, if present, appears therefore less important than the change in the number of active cells. These results are in agreement with previous and recent observations made by Russell and Clermont (1977), who reported the presence of spermatocytes and spermatids in hypophysectomized animals and suggested that hormones control the efficiency (cell numbers), but not the qualitative properties, of differentiation steps in spermatogenesis.

Of course, the question remains : via which biochemical mechanisms does the Sertoli cell cause rapid degeneration of some spermatocytes after withdrawal of FSH and testosterone?

27 e Congrès international des Sciences physiologiques, Symposium « Germ and somatic cell inferaction 》 Poris, 21-23 juillef 1977.

Résumé. Plusieurs paramètres biochimiques ont été étudiés dans les cellules de Sertoli et les cellules germinales du testicule de rat. Des récepteurs aux androgènes sont présents dans les cellules de Sertoli, mais pas dans les cellules germinales provenant du même testicule.

Les cellules de Sertoli isolées, incubées en présence de ${ }^{3} \mathrm{H}$-leucine, sécrètent en plus de l'ABP, de nombreuses autres protéines marquées. La sécrétion de ces protéines est stimulée par la présence de testostérone, de FSH ou de dibutyryl cAMP. En outre, les cellules de Sertoli semblent sécréter une substance comparable à l'inhibine. Dans les spermatocytes pachytène isolés, l'incorporation de ${ }^{3} \mathrm{H}$-uridine dans I'ARN reste constante pendant $8 \mathrm{~h}$, puis diminue ensuite. Une incorporation relativement plus importante dans le $32 \mathrm{~S}$ rARN que dans le $28 \mathrm{~S}$ apparaît dans le profil électrophorétique de l'ARN marqué et doit refléter un délai dans la duplication de l'ARN ribosomal dans les spermatocytes. 


\section{References}

BEURDEN W. M. O. VAN, ROODNAT B., DE JONG F. H., MULDER E., VAN DER MOLEN H. J., 1976. Hormonal regulation of $\mathrm{LH}$ stimulation of testosterone production in isolated Leydig cells of immature rats : the effect of hypophysectomy, FSH and estradiol-17 $\beta$. Steroids, 28, 847-864.

CLERMONT Y., HARVEY S. C., 1967. Effects of hormones on spermatogenesis in the rat, 173-189. In WOLSTENHOLME G. E. W., O'CONNOR M., Endocrinology of the testis, Ciba Found. Coll. Endocr., 16.

FAWCETT D. W., 1975. The ultrastructure and functions of the Sertoli cell, 21-58. In Handbook of Physiology, 5, Sect. 7, Physiol. Soc., Washington D. C.

GALENA H. J., PILLAI A. K., TERNER C., 1974. Progesterone and androgen receptors in nonflagellate germ cells of the rat testis. J. Endocr., 63, 223-237.

GROOTEGOED J. A., PETERS M. J., MULDER E., ROMMERS F. F. G., VAN DER MOLEN H. J., 1977 a. Absence of a nuclear androgen receptor in isolated germinal cells of rat testis. Molec. cell. Endocr., 9, 159-167.

GROOTEGOED J. A., GROLLÉ-HEY A. H., ROMMERTS F. F. G., VAN DER MOLEN H. J., $1977 b$. RNA synthesis in vitro in primary spermatocytes isolated from rat testis. Biochem. J., 168, 23-31.

LOUIS B. G., FRITZ I. B., 1977. Stimulation by androgens of the production of androgen binding protein by culfured Sertoli cells. Molec. cell. Endocr., 7, 9-16.

LYON M. F., GLENISTER P. H., LAMOREUX M. L., 1975. Normal spermatozoa from androgenresistant germ cells of chimaeric mice and the role of androgen in spermatogenesis. Nature, 258, 620-622.

MULDER E., PETERS M. J., DE VRIES J., VAN DER MOLEN H. J., 1975. Characterization of a nuclear receptor for testosterone in seminiferous tubules of mature rat testes. Molec. cell. Endocr., 2 , 171-182.

ROMMERTS F. F. G., CLOTSCHER W. F., VAN DER MOLEN H. J., 1977. Rapid concentration and dialysis of proteins with single hollow fibres. Possible applications in analysis of protein secretion by isolated cells and steroid radioimmuno assays. Anal. Biochem., 82, 503-511.

RUSSELL L., 1977. Desmosome-like junctions between Sertoli and germ cells in the rat testis. Am. J. Anat., 148, 301-312.

RUSSELL L. D., CLERMONT Y., 1977. Degeneration of germ cells in normal hypophysectomized and hormone treated hypophysectomized rats. Anat. Rec., 187, 347-365.

SANBORN B. M., STEINBERGER A., MEISTRICH M. L., STEINBERGER E., 1975. Androgen binding sites in testis cell fractions as measured by a nuclear exchange assays. J. Sieroid Biochem., 6, 1459-1465. 